\title{
Micropropagation of Calophyllum brasiliense (Cambess.) from nodal segments
}

\author{
S. S. Silveira ${ }^{a}$, R. Cordeiro-Silva ${ }^{b}, J$. Degenhardt-Goldbach ${ }^{c}$ and M. Quoirin ${ }^{b *}$ \\ aPrograma de Pós-graduação em Agronomia (Produção Vegetal), Laboratório de Micropropagação, \\ Departamento de Botânica, Universidade Federal do Paraná - UFPR, Av. Coronel Francisco Heráclito dos Santos, \\ s/n, Jardim das Américas, CEP 81530-900, Curitiba, PR, Brazil \\ 'Programa de Pós-graduação em Botânica, Laboratório de Micropropagação, Departamento de Botânica, \\ Universidade Federal do Paraná - UFPR, Av. Coronel Francisco Heráclito dos Santos, s/n, \\ Jardim das Américas, CP 19031, CEP 81531-980, Curitiba, PR, Brazil \\ ${ }^{\mathrm{c}}$ Embrapa Florestas, Estrada da Ribeira, Km 111, CEP 83411-000, Colombo, PR, Brazil \\ *e-mail: mquoirin@ufpr.br
}

Received: November 18, 2014 - Accepted: June 3, 2015 - Distributed: August 31, 2016

(With 1 figure)

\begin{abstract}
Micropropagation of Calophyllum brasiliense Cambess. (Clusiaceae) is a way to overcome difficulties in achieving large-scale plant production, given the recalcitrant nature of the seeds, irregular fructification and absence of natural vegetative propagation of the species. Cultures were established using nodal segments $2 \mathrm{~cm}$ in length, obtained from 1-2 year old seedlings, maintained in a greenhouse. Mercury chloride and Plant Preservative Mixture ${ }^{\mathrm{TM}}$ were used in the surface sterilizing stage, better results being achieved with Plant Preservative Mixture ${ }^{\mathrm{TM}}$ incorporation in culture medium, at any concentration. Polyvinylpyrrolidone, activated charcoal, cysteine, ascorbic acid or citric acid were added to the culture medium to avoid oxidation. After 30 days of culture, polyvinylpirrolidone and ascorbic acid gave better results, eliminating oxidation in most explants. For shoot multiplication, benzylaminopurine was used in concentrations of 4.4 and $8.8 \mu \mathrm{M}$ in Woody Plant Medium, resulting in an average of 4.43 and 4.68 shoots per explant, respectively, after 90 days. Indole-3-butyric acid and $\alpha$-naphthalene acetic acid were used to induce root formation, reaching a maximum rooting rate of $24 \%$ with $20 \mu \mathrm{M} \alpha$-naphthalene acetic acid. For acclimatization. the rooted plants were transferred to Plantmax ${ }^{\circledR}$ substrate and cultured in a greenhouse, reaching $79 \%$ of survival after 30 days and $60 \%$ after one year.
\end{abstract}

Keywords: benzylaminopurine, Clusiaceae, guanandi, woody plant.

\section{Micropropagação de Calophyllum brasiliense (Cambess.) a partir de segmentos nodais}

\section{Resumo}

A micropropagação de Calophyllum brasiliense Cambess. (Clusiaceae) é uma maneira de superar dificuldades para sua produção em larga escala, devido à natureza recalcitrante das sementes, frutificação irregular e ausência de propagação vegetativa natural da espécie. Culturas foram estabelecidas utilizando segmentos nodais com $2 \mathrm{~cm}$ de comprimento, obtidos de plantas com 1 a 2 anos de idade, mantidas em casa de vegetação. Cloreto de mercúrio e Plant Preservative Mixture $^{\mathrm{TM}}$ foram utilizados durante a etapa de desinfestação, com melhores resultados alcançados com a incorporação de Plant Preservative Mixture ${ }^{\mathrm{TM}}$ ao meio de cultura. Polivinilpirrolidona, carvão ativado, cisteína, ácido ascórbico ou ácido cítrico foram adicionados ao meio de cultura para evitar a oxidação dos explantes. Após 30 dias de cultivo, o uso de polivinilpirrolidona ou ácido ascórbico proporcionou melhores resultados, eliminando a oxidação na maioria dos explantes. Para multiplicação das brotações, benzilaminopurina foi usada em concentrações de 4.4 e $8.8 \mu \mathrm{M}$ em meio WPM, resultando em uma média de 4.43 e 4.68 brotações por explante, respectivamente, após 90 dias. Ácido indol-3-butírico e ácido $\alpha$-naftaleno acético foram usados para a indução de raízes, alcançando um enraizamento máximo de $24 \%$ com o uso de $20 \mu \mathrm{M}$ de ácido $\alpha$-naftaleno acético. As plantas enraizadas foram transferidas para substrato Plantmax ${ }^{\circledast}$ e cultivadas em casa de vegetação, alcançando $79 \%$ de sobrevivência após 30 dias e $60 \%$ após um ano.

Palavras-chave: benzilaminopurina, Clusiaceae, guanandi, planta lenhosa. 


\section{Introduction}

Calophyllum brasiliense Cambess. (Clusiaceae), commonly known in Brazil as guanandi, olandi or jacareúba, is an important woody plant native to tropical America. The species occurs in flooded forests and is well adapted to hypoxic conditions (Marques and Joly, 2000) and it is therefore indicated for restoration programs (Nery et al., 2007). The plant has potential for use in the timber industry due to the good quality of its wood (Flores, 2002; Cole et al., 2011) and also presents medicinal properties (Noldin et al., 2006; Souza et al., 2009; Brenzan et al., 2012), including cancer chemopreventive activity (Ito et al., 2002). Moreover, due to wood exploitation and environmental pressure, natural populations of $C$. brasiliense have been reduced in the recent years (Marques and Joly, 2000) and this species is listed as endangered in some Brazilian states such as São Paulo (São Paulo, 2008).

Natural propagation of this species occurs through seeds, but their recalcitrant nature (Carvalho et al., 2006) and the irregular fructification, occurring at 41-month intervals (Fischer and Dos Santos, 2001) limit its propagation. So far, no viable vegetative propagation system has been reported for this species.

Development of a tissue culture protocol is an alternative for the propagation of species with limited large-scale production. Micropropagation, compared with other traditional methods of propagation, has many advantages and its applications in horticulture, agriculture and forestry are spreading worldwide (Rathore et al., 2013). Micropropagation requires only a small explant for the initiation of culture (George and Debergh, 2008). In addition, the plants growing in vitro are kept in a controlled environment, which allows the effective cloning of economically important plants (Iliev et al., 2010).

This study aims to develop a protocol for guanandi micropropagation, using nodal segments obtained from greenhouse plants.

\section{Material and Methods}

\subsection{Culture media and conditions}

The basal medium consisted of Woody Plant Medium (WPM) salts and vitamins (Lloyd and McCown, 1980) supplemented with 30 g.L. $\mathrm{L}^{-1}$ sucrose and solidified with 6 g.L $L^{-1}$ agar $\left(\operatorname{Vetec}^{\circledR}\right)$. Different plant growth regulators (PGRs), antioxidants or Plant Preservative Mixture (PPM ${ }^{\mathrm{TM}}$ ) were added. The $\mathrm{pH}$ of the media was adjusted to 5.8 prior to autoclaving at $121^{\circ} \mathrm{C}$ for $20 \mathrm{~min}$.

At all in vitro stages, the explants were kept in a growth room at $19 \pm 2{ }^{\circ} \mathrm{C}$ at night and $26 \pm 1^{\circ} \mathrm{C}$ by day under a 16h-photoperiod and a white fluorescent light with photosynthetic photon flux density of about $30 \mu \mathrm{mol} \cdot \mathrm{m}^{-2} \cdot \mathrm{s}^{-1}$.

\subsection{Surface sterilization of explants}

\subsubsection{Effect of mercury chloride}

Cultures of $C$. brasiliense were established using nodal segments $2 \mathrm{~cm}$ in length, obtained from 1-2 year old seedlings, maintained in a greenhouse. The plants were treated weekly with a $0.3 \%$ Cercobin ${ }^{\circledR}$ solution (w/v), and manually irrigated every $2 \mathrm{~d}$.

Young and soft nodal segments were excised from the mother plant. The leaves were cut and the explants washed in soapy water for $5 \mathrm{~min}$ and then rinsed in distilled water. All subsequent operations were carried out in a laminar air flow chamber. The explants were surface sterilized in $70 \%$ ethanol for $1 \mathrm{~min}$, followed by sodium hypochlorite ( NaOCl) $5 \%(\mathrm{v} / \mathrm{v})$ plus $0.01 \%$ Tween $-20^{\circledR}$ for $10 \mathrm{~min}$ and mercury chloride $\left(\mathrm{HgCl}_{2}\right)(0.1$ and $0.2 \% \mathrm{w} / \mathrm{v})$ for 2 to $4 \mathrm{~min}$ under constant agitation. The explants were rinsed six times in autoclaved distilled water.

The terminal ends of the explants were sectioned to eliminate the oxidized parts. The apical bud was excised, keeping two axillary buds per explant. The explants were placed individually in a vertical position (see Figure 1a) in flasks ( $5 \mathrm{~cm}$ high $\times 3 \mathrm{~cm}$ diameter), containing $10 \mathrm{ml}$ of culture medium, sealed with an aluminum cover.

Fungal and bacterial contamination and survival were evaluated after $30 \mathrm{~d}$. The experimental design was a factorial arrangement, considering the concentration of $\mathrm{HgCl}_{2}(0.1$ or $0.2 \%)$ and exposure time to the solution ( 2 or $4 \mathrm{~min}$ ). Five replications were used, each containing 10 explants in individual vials, making a total of 50 explants per treatment.

\subsubsection{Effect of $\mathrm{PPM}^{\mathrm{TM}}$ on culture medium}

Excision and surface sterilization of the nodal segments were performed as described above, with the following changes. $\mathrm{HgCl}_{2}$ was not used and the explants were rinsed in autoclaved distilled water only three times. Explants were placed individually in a vertical position in test tubes (15 cm high x $2 \mathrm{~cm}$ diameter) containing $10 \mathrm{ml}$ of culture medium without PGRs with concentrations of $0.2,0.4$ or $0.8 \%(\mathrm{v} / \mathrm{v})$ of Plant Preservative Mixture $\left(\mathrm{PPM}^{\mathrm{TM}}\right)$, maintaining a control without PPM ${ }^{\mathrm{TM}}$.

Contamination by bacteria and fungi and survival were assessed after $30 \mathrm{~d}$. The experimental design was completely randomized (CRD) with five replications of 10 explants each, totalizing 50 explants per treatment.

\subsection{Effect of anti-oxidant and absorbent treatments}

Nodal segments, $2 \mathrm{~cm}$ long, were surface sterilized as described above, with the addition of $0.1 \%(\mathrm{w} / \mathrm{v})$ mercury chloride solution for $5 \mathrm{~min}$. The explants were inoculated in WPM medium without PPM ${ }^{\mathrm{TM}}$. For each treatment, one of the following compounds was added to the culture medium: 1 g. $\mathrm{L}^{-1}$ polyvinylpyrrolidone (PVP-40), 1 g.L $\mathrm{L}^{-1}$ activated charcoal (AC), $200 \mathrm{mg} . \mathrm{L}^{-1}$ cysteine (Cys), ascorbic acid (AA) or citric acid (CA), maintaining the control without addition of any substance.

After $30 \mathrm{~d}$ of culture, the oxidation and intense oxidation (when the phenol compounds are diffused into the culture medium) of the explants were assessed. The experimental design was CRD with five replications of eight plants each (one explant per test tube) for each treatment. The experiment was repeated once. 

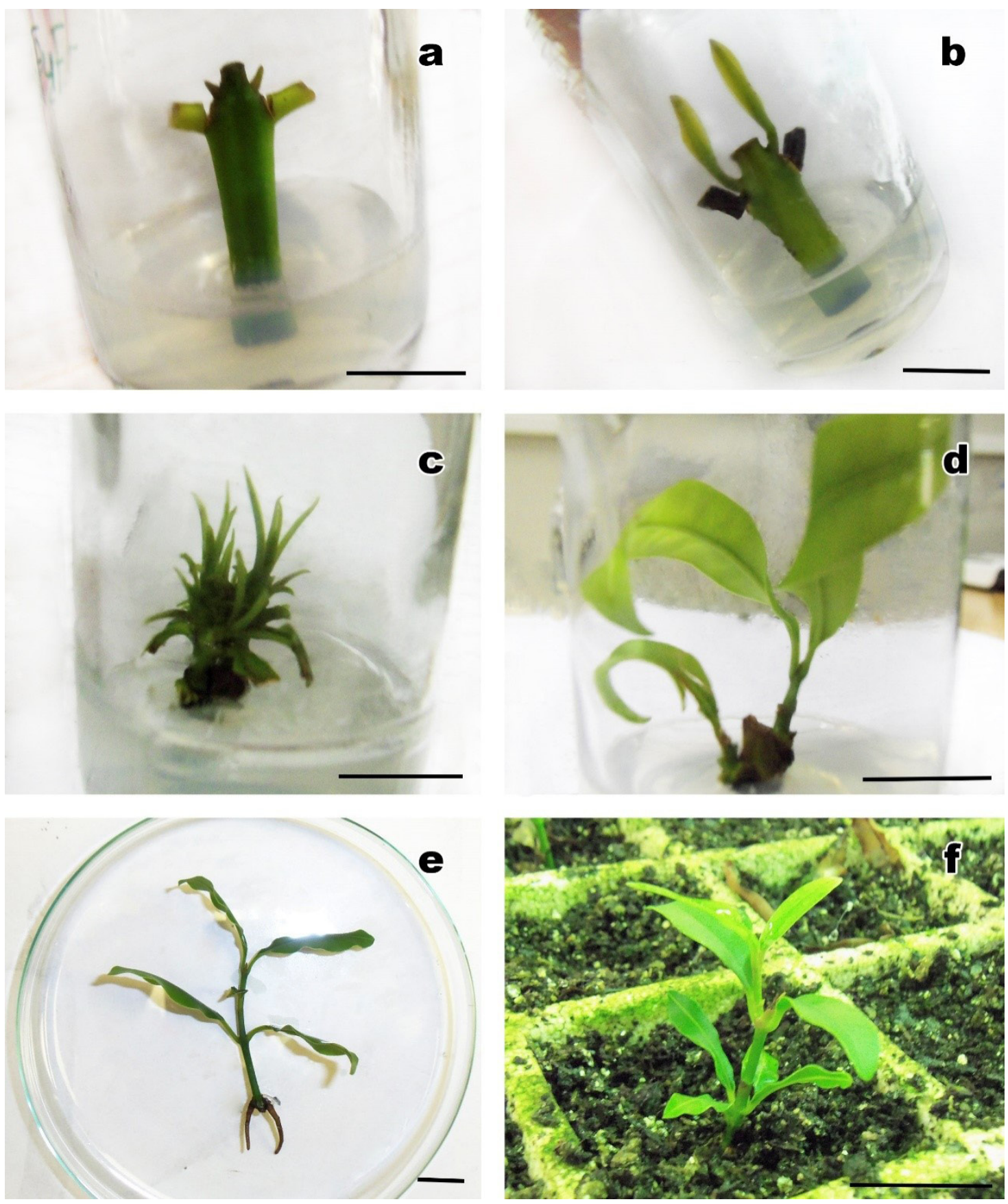

Figure 1. Micropropagation of Calophyllum brasiliense: (a) nodal segment in WPM medium without PGRs after surface sterilization; (b) $60 \mathrm{~d}$ after inoculation; (c) multiplication in WPM medium supplemented with $8.8 \mu \mathrm{M}$ BA; (d) elongated shoot on PGR-free medium, after $120 \mathrm{~d}$; (e) rooted explant after $7 \mathrm{~d}$ in WPM culture medium supplemented with $20 \mu \mathrm{M}$ NAA and $60 \mathrm{~d}$ in PGR-free medium; (f) acclimatized plant in a 1:1 mixture of Plantmax ${ }^{\circledR}$ and vermiculite, 6 months after transplanting. Bar: $1 \mathrm{~cm}$.

\subsection{Shoot multiplication}

The explants cultured for 30d in WPM medium, free from bacterial or fungal contamination, were placed on the same medium supplemented with 6-benzylaminopurine (BA). Different concentrations of BA were incorporated into the medium $(4.4,8.8$ and $11 \mu \mathrm{M})$ for multiple shoot induction, maintaining a control treatment without any PGR. The terminal ends of the explants were cut, maintaining the original nodal segment. Two explants were placed in each jar, closed with a polypropylene cap, containing 40 $\mathrm{ml}$ culture medium each. 
The explants were transferred to the culture medium with the same concentrations of BA every $30 \mathrm{~d}$. During subcultures, the initial explant was maintained only by cutting the oxidized ends and larger leaves. In preliminary tests, individualized shoots under $2 \mathrm{~cm}$ length suffered necrosis. Therefore, only shoots longer than $3 \mathrm{~cm}$ were isolated and subcultured, being excised from the original explants. The number of shoots was evaluated after 30 , 60 and $90 \mathrm{~d}$.

The experimental design was CRD, consisting of seven replications with five flasks and 2 explants per flask, totaling 70 explants for each concentration of BA. The experiment was repeated once.

\subsection{Rooting}

Shoots larger than $3 \mathrm{~cm}$, obtained after 6 months in multiplication medium with BA, were isolated and used for rooting. The base of the explant was cut in a double bevel and shoots were transferred to WPM medium containing 10 or $20 \mu \mathrm{M}$ indole-3-butyric acid (IBA) or $\alpha$-naphthalene acetic acid (NAA) and maintained for $7 \mathrm{~d}$ in the dark. Two nodal segments were placed in each jar. After $7 \mathrm{~d}$ in the dark in a medium with auxin, the shoots were transferred to identical WPM, but without any PGR. The percentage of rooted explants and number of roots per shoot was scored after $60 \mathrm{~d}$, and a subculture to identical media, without PGRs, was performed after the first month.

The experimental design was CRD with five replications of six plants each, for 30 shoots per treatment.

\subsection{Acclimatization}

The rooted plants were transferred to Plantmax ${ }^{\circledR}$ substrate. They were maintained at $25 \pm 2^{\circ} \mathrm{C}$, with automatic irrigation for 5 min every $6 \mathrm{~h}$.

\subsection{Statistical analysis}

Data were subjected to Bartlett's test for homogeneity and then Deviance analysis. The treatment means comparisons were carried out with Tukey's test at $0.05 \%$ significance level.

\section{Results}

\subsection{Surface sterilization of explants}

\subsubsection{Effect of mercury chloride}

Explants contaminated by fungi were observed after $7 \mathrm{~d}$ of in vitro culture, while the bacteria began to appear only after $14 \mathrm{~d}$. After $30 \mathrm{~d}$ of culture, total mean contamination was $26.5 \%$, and bacterial contamination was $22 \%$ (as shown in Table 1). According to the Tukey's test, using two concentrations of mercury chloride $\left(\mathrm{HgCl}_{2}\right)$ resulted in no significant differences between the means, indicating that this factor has no influence on infection rates or necrosis, but influenced survival of explants. When considering the length of exposure to the disinfectant agent, the differences between the results of bacterial contamination were significant, indicating that the longer the exposure to $\mathrm{HgCl}_{2}$, the lower the rate of bacterial contamination (see Table 1).

\subsubsection{Effect of $P P M^{\mathrm{TM}}$ on explant disinfection}

After $30 \mathrm{~d}$ of culture, the average survival of explants was $82.5 \%$, being higher in the case of explants maintained in a medium with PPM ${ }^{\mathrm{TM}}$, reaching up to $92 \%$ (see Table 2). The statistical analysis showed that the use of PРМ'М, regardless of concentration, was highly effective in combating bacteria, whereas the concentration of $0.4 \%$ eliminated them. The highest concentration tested $(0.8 \%)$ was more effective in reducing fungal contamination, but

Table 1. Effect of concentration and time of exposure to mercury chloride $\left(\mathrm{HgCl}_{2}\right)$ on contamination of Calophyllum brasiliense nodal segments and survival, $30 \mathrm{~d}$ after in vitro introduction in WPM medium without PGRs.

\begin{tabular}{|c|c|c|c|c|c|c|c|c|}
\hline \multirow{2}{*}{$\begin{array}{c}\mathrm{HgCl}_{2} \\
\text { concentration } \\
(\%) \\
\end{array}$} & \multicolumn{2}{|c|}{$\begin{array}{c}\text { Fungal contamination } \\
(\%)\end{array}$} & \multicolumn{2}{|c|}{$\begin{array}{c}\text { Bacterial contamination } \\
(\%)\end{array}$} & \multicolumn{2}{|c|}{$\begin{array}{c}\text { Necrosis } \\
(\%)\end{array}$} & \multicolumn{2}{|c|}{$\begin{array}{c}\text { Survival } \\
(\%)\end{array}$} \\
\hline & $2 \mathrm{~min}$ & & & & & & & \\
\hline 0.1 & $6.0 \pm 6.6 \mathrm{Aa}$ & & $6.0 \pm 12.3 \mathrm{Aa}$ & & & & $8.0 \pm 13.1 \mathrm{Aa}$ & $86.0 \pm 9.7 \mathrm{Aa}$ \\
\hline 0.2 & $4.0 \pm 5.5 \mathrm{Aa}$ & $6.0 \pm 6.6 \mathrm{Aa}$ & $32.0 \pm 13.1 \mathrm{Aa}$ & $20.0 \pm 11.2 \mathrm{Ab}$ & $12.0 \pm 9.1 \mathrm{Aa}$ & $8.0 \pm 7.6 \mathrm{Aa}$ & $58.0 \pm 13.8 \mathrm{Ba}$ & $66.0 \pm 13.3 \mathrm{Ba}$ \\
\hline
\end{tabular}

For the same variable, means horizontally followed by different lower letters, and vertically by upper letters, are significantly different by Tukey's test at $\mathrm{p}<0.05$.

Table 2. Contamination and survival of nodal segments of Calophyllum brasiliense after $30 \mathrm{~d}$ of culture in WPM medium supplemented with $\mathrm{PPM}^{\mathrm{TM}}$.

\begin{tabular}{|c|c|c|c|c|}
\hline $\begin{array}{c}\mathbf{P P M}^{\mathrm{T}} \\
\text { concentration } \\
(\%) \\
\end{array}$ & $\begin{array}{c}\text { Fungal } \\
\text { contamination }(\%)\end{array}$ & $\begin{array}{c}\text { Bacterial } \\
\text { contamination }(\%)\end{array}$ & Necrosis $(\%)$ & Survival (\%) \\
\hline 0 & $18 \pm 10.8 \mathrm{a}$ & $20 \pm 11.2 \mathrm{a}$ & $4 \pm 5.5^{\mathrm{ns}}$ & $58 \pm 13.8 \mathrm{a}$ \\
\hline 0.2 & $8 \pm 7.6 \mathrm{ab}$ & $2 \pm 3.9 \mathrm{~b}$ & $2 \pm 3.9^{\mathrm{ns}}$ & $88 \pm 9.1 b$ \\
\hline 0.4 & $6 \pm 6.6 \mathrm{ab}$ & $0 \pm 0.0 \mathrm{~b}$ & $2 \pm 3.9 \mathrm{~ns}$ & $92 \pm 7.6 b$ \\
\hline 0.8 & $2 \pm 3.9 \mathrm{~b}$ & $0 \pm 0.0 \mathrm{~b}$ & $6 \pm 6.6^{\mathrm{ns}}$ & $92 \pm 7.6 b$ \\
\hline Mean & 8.5 & 5.5 & 3.5 & 82.5 \\
\hline
\end{tabular}

Means followed by different letters are significantly different by Tukey's test at $\mathrm{p}<0.05 .{ }^{\text {ns }}$ not statistically significant. 
all tested concentrations were effective. The necrosis rate was low (average 3.5\%) and predominantly observed in the treatment with $0.8 \%$ biocide, indicating that an increase in concentration can result in increased stress to the tissues and a consequent increase in the production of phenolic compounds.

\subsection{Effect of anti-oxidant and absorbents treatment}

After $30 \mathrm{~d}$ of culture, $85 \%$ of the explants in WPM without antioxidants showed signs of oxidation. In $35 \%$ of these, the oxidation was considered severe and not restricted to the base of the explant (as shown in Table 3). The use of 1 g.L. $\mathrm{L}^{-1}$ PVP-40 was effective in preventing oxidation of the base of the explants. To prevent intense oxidation, observed when the phenol compounds were released and diffused into the culture medium, both PVP and ascorbic acid were effective.

\subsection{Shoot multiplication}

The use of BA during in vitro multiplication of nodal segments is necessary, since the maximum number of shoots per nodal segment is low on a medium without cytokinin, usually 2 per explant (Figure 1b). This number was elevated with BA application (Figure 1c). The results did not differ statistically for the three concentrations for 60 and $90 \mathrm{~d}$ (Table 4), but the concentration of $11 \mu \mathrm{M}$ of BA resulted in necrosis of many explants (data not shown).

\subsection{Rooting and acclimatization}

After $60 \mathrm{~d}$ in culture on WPM medium supplemented with IBA or NAA (see Figure 1e), the rooting of shoots was low, with an average of $14 \%$ (as shown in Table 5).
According to the statistical analysis, there were no differences among the auxins types and concentrations tested.

Results of the acclimatization treatment showed that all the plants with roots were successfully acclimatized (see Figure 1f). After $30 \mathrm{~d}$ in a greenhouse, $79 \%$ of the plants survived and grew. After one year, $60 \%$ of rooted plants survived in greenhouse.

\section{Discussion}

Preliminary tests of nodal segment disinfection using only sodium hypochlorite $(\mathrm{NaOCl})$ for surface sterilization were inefficient, with an average contamination above $40 \%$. In addition, high concentrations of $\mathrm{NaOCl}(7.5 \%)$ damaged tissues, causing high rates of oxidation and necrosis $(>50 \%)$. Explant damage due to high concentrations of sodium hypochlorite, also were observed in peach (Ahmad et al., 2003), Allanblackia stuhlmannii (Neondo et al., 2011) and Carya illinoensis nodal segments (Aftab and Preece, 2007). According to Mng'Omba et al. (2012), $\mathrm{HgCl}_{2}$ is stronger than $\mathrm{NaOCl}$, which is the likely reason for its effectiveness in combating fungi, even endogenous species. The mortality of the cultures may be higher due to damage caused by stronger disinfectants, as was the case with Calophyllum apetalum (Nair and Seeni, 2003).

When compared to the experiment with $\mathrm{HgCl}_{2}$, the survival rates were higher with $\mathrm{PPM}^{\mathrm{TM}}$, indicating the better effects of PPM ${ }^{\mathrm{TM}}$ for disinfection, controlling both fungi and bacteria. This suggests that $\mathrm{PPM}^{\mathrm{TM}}$ is preferable as $\mathrm{HgCl}_{2}$ is highly toxic, but necessary for contamination control in some cultures. Similar results were obtained in

Table 3. Effect of different antioxidants added in WPM culture medium on oxidation of nodal segments of Calophyllum brasiliense after $30 \mathrm{~d}$ of culture.

\begin{tabular}{cccc}
\hline Antioxidant & Concentration & \% oxidized explants & \% intense oxidation* \\
\hline Control & - & $85 \pm 16.3 \mathrm{a}$ & $35 \pm 20.5 \mathrm{a}$ \\
PVP-40 & $1 \mathrm{~g} \cdot \mathrm{L}^{-1}$ & $15 \pm 13.7 \mathrm{c}$ & $0 \pm 00.0 \mathrm{~b}$ \\
Activated charcoal & $1 \mathrm{~g} \cdot \mathrm{L}^{-1}$ & $73 \pm 22.2 \mathrm{ab}$ & $29 \pm 13.3 \mathrm{ab}$ \\
Cystein & $200 \mathrm{mg} \cdot \mathrm{L}^{-1}$ & $74 \pm 17.1 \mathrm{ab}$ & $22 \pm 22.0 \mathrm{ab}$ \\
Citric Acid & $200 \mathrm{mg} \cdot \mathrm{L}^{-1}$ & $77 \pm 13.7 \mathrm{a}$ & $41 \pm 15.6 \mathrm{a}$ \\
Ascorbic Acid & $200 \mathrm{mg} \cdot \mathrm{L}^{-1}$ & $42 \pm 14.3 \mathrm{bc}$ & $0 \pm 00.0 \mathrm{~b}$ \\
Mean & - & 61 & 21 \\
\hline
\end{tabular}

Means followed by different letters are significantly different by Tukey's test at $\mathrm{p}<0.05$. $*$ When phenolic compounds diffused to the culture medium.

Table 4. Effect of BA concentration in WPM culture media on the number of shoots per nodal segment of Calophyllum brasiliense after 30,60 and $90 \mathrm{~d}$ of culture in multiplication medium.

\begin{tabular}{cccc}
\hline \multirow{2}{*}{ BA concentration $(\boldsymbol{\mu M})$} & \multicolumn{3}{c}{ Mean number of shoots per explant } \\
\cline { 2 - 4 } & 30d & 60d & 90d \\
\hline 0 & $1.7(3) \pm 0.2 \mathrm{a}$ & $1.7(3) \pm 0.2 \mathrm{a}$ & $2.0(5) \pm 0.2 \mathrm{a}$ \\
4.4 & $2.1(5) \pm 0.3 \mathrm{a}$ & $3.1(6) \pm 0.3 \mathrm{~b}$ & $4.4(14) \pm 0.8 \mathrm{~b}$ \\
8.8 & $2.5(6) \pm 0.4 \mathrm{~b}$ & $3.0(6) \pm 0.5 \mathrm{~b}$ & $4.7(18) \pm 1.1 \mathrm{~b}$ \\
11 & $2.4(5) \pm 0.4 \mathrm{~b}$ & $3.2(8) \pm 0.8 \mathrm{~b}$ & $4.8(13) \pm 0.7 \mathrm{~b}$ \\
Mean & 2.2 & 2.8 & 4.0 \\
\hline
\end{tabular}

Means followed by different letters are significantly different by Tukey's test at $p<0.05$. Numbers in parenthesis indicate maximum number of shoots per explant. 
Table 5. Effect of two auxins added to a WPM culture medium on rooting of nodal segments of Calophyllum brasiliense after $60 \mathrm{~d}$ of culture.

\begin{tabular}{ccc}
\hline Treatment & \% rooting & $\begin{array}{c}\text { Mean number of } \\
\text { roots by explant }\end{array}$ \\
\hline $10 \mu \mathrm{M}$ IBA & $8.0 \pm 10.9^{\mathrm{ns}}$ & $1.5(2) \pm 0.89^{\mathrm{ns}}$ \\
$20 \mu \mathrm{M}$ IBA & $8.0 \pm 10.9^{\mathrm{ns}}$ & $3.5(4) \pm 1.95^{\mathrm{ns}}$ \\
$10 \mu \mathrm{M}$ NAA & $24.0 \pm 32.9^{\mathrm{ns}}$ & $1.8(5) \pm 0.93^{\mathrm{ns}}$ \\
$20 \mu \mathrm{M}$ NAA & $16.0 \pm 16.7^{\mathrm{ns}}$ & $2.3(3) \pm 1.34^{\mathrm{ns}}$ \\
Mean & 14 & 2.3 \\
\hline
\end{tabular}

Means followed by different letters are significantly different by Tukey's test at $p<0.05$. The numbers in parenthesis indicate maximum number of roots in an explant. ${ }^{n s}$ not statistically significant.

cultures of Citrus sinensis (Niedz and Bausher, 2002) and Swietenia macrophylla (Flores, 2006), demonstrating the effectiveness of PPM ${ }^{\mathrm{TM}}$. For Citrus sinensis, the use of $2 \%$ of this biocide was extremely toxic, as it completely inhibited the development of shoots. This suggests that the toxicity of PPM ${ }^{\mathrm{TM}}$ is low, but increases at higher concentrations. Consequently $0.2 \% \mathrm{PPM}^{\mathrm{TM}}$ was further used in the present study, with a significant reduction in contamination of the explants. Reducing the concentration to $0.1 \%$ did not diminish its effectiveness and total contamination rates ranged between 5 and $15 \%$.

Tropical woody plant tissues are quite susceptible to in vitro browning, a direct result of stress and chemical reactions induced by polyphenol oxidases and other enzymes, and the resulting phenol compounds react with oxygen to form quinine compounds, generally inhibitory of plant growth (Krikorian, 1988; Ahmad et al., 2013; Chang and Shu, 2013). Despite the action of both AC and PVP as adsorbents, such substances have not shown the same effectiveness to control browning in Calophyllum brasiliense tissues. This can be explained by the fact that AC adsorbs various substances, harmful or not, not being compound-selective and adsorbing also PGRs, minerals and vitamins from the culture medium (Azofeifa-Delgado, 2009; Zhou et al., 2010). In addition, in the present study AC caused a reduction in the development of explants and about $50 \%$ chlorosis followed by necrosis, as observed for Pistacia vera and P. atlantica too (Mederos-Molina and Trujillo, 1999). PVP, on the other hand, is a polyamide that prevents oxidation and polymerization of phenol compounds, being selective for this kind of substance (Zhou et al., 2010). As for guanandi, PVP was efficient in avoiding oxidation in the case of calluses of Eucalyptus tereticornis (Subbaiah and Minocha, 1990), in various types of explants of Pouteria lucuma (Jordan and Oyanedel, 1992) and in multinodal segments of Leucadendron (Suárez et al., 2010).

AA does not interact directly with polyphenol, but prevents the darkening of crops by reducing oxidized substrates (Ahmad et al., 2013). AA acts as a reducing agent, capturing hydrogen peroxide, superoxide, hydroxyl and other oxygen radicals, acting as a broad-spectrum key antioxidant (Ali and Alqurainy, 2006; George and Davies, 2008; Suárez et al., 2010). This antioxidant was effective for guanandi, as well as cultures of Pouteria lucuma (Jordan and Oyanedel, 1992), Leucadendron (Suárez et al., 2010) and Musa sp. (Chang and Shu, 2013).

For guanandi cultures, CA and Cys were not effective at $200 \mathrm{mg} . \mathrm{L}^{-1}$. Both substances act indirectly as antioxidants. CA functions as a chelating agent, capturing ions, especially copper (Nāwar, 1996; Gregory, 1996; Raju and Bawa, 2006). Differently, Cys is a component of glutathione molecules that removes hydrogen peroxide and other reactive oxygen species (Ali and Alqurainy, 2006).

Comparing the multiplication results with those obtained in the culture of nodal segments of C. apetalum, where the maximum number of shoots per explant was 5.3 after 5 weeks, even with the use of $13 \mu \mathrm{M}$ BA(Nair and Seeni, 2003), we conclude that the rate of multiplication of guanandi segments is satisfactory (mean rate of 4.8 per month and up to 18 shoots per explant after 12 weeks). However, very young shoots $(<2 \mathrm{~cm})$ should remain longer in multiplication medium, or transferred to a PGR-free medium to elongate, because they cannot be separated and transferred to a rooting medium without suffering necrosis. Preliminary tests indicate that the individualization of very short shoots results in the loss of $100 \%$ of explants.

The rooting phase is sometimes a bottleneck during micropropagation and auxins are essential for rooting of the most difficult-to-root species (Maynard and Bassuk, 1991; De Klerk, 2002; Nas and Read, 2004). In preliminary tests, no rooting was observed for explants maintained in culture medium without added auxins (data not shown). For Calophyllum brasiliense, roots formed with both NAA or IBA were similar, but NAA induced callus formation. For other plants belonging to the Clusiaceae family, such as Garcinia indica (Malik et al., 2005) and G. mangostana (Goh et al., 1990), NAA induced shorter and thicker roots than IBA, and also caused callus formation. For Garcinia quaesita shoots regenerated from leaf explants, neither IBA nor NAA were efficient for rooting, and none of the micropropagated shoots produced any roots (Farzana et al., 2010). Woody plants, especially of forest species, are difficult to root and the protocol needs to be well adjusted for this step to be successful.

The acclimatization success rate was similar to the $80 \%$ of survival with Calophyllum inophyllum (Thengane et al., 2006). For Garcinia indica, the survival rate was higher, reaching 90\% (Malik et al., 2005).

\section{Conclusion}

Micropropagation of Calophyllum brasiliense, using nodal segments as starting material, is possible. PPM ${ }^{\mathrm{TM}}$ biocide may be added to the culture medium to reduce contamination of the explants. During multiplication, the use of a cytokinin is recommended in order to promote the production of sprouts, as the number of shoots is low without its use. BA may be used at a concentration of 4.4 or $8.8 \mu \mathrm{M}$ and a higher concentration resulted in 
lower vigor and necrosis of the explants. The rooting of the shoots is low and some alternatives has to be tested in order to increase the rooting rate

\section{Acknowledgements}

The author is grateful to Embrapa-Florestas for providing mother-plants for this study, to Eileen Bagyary for editing the manuscript and Coordenação de Aperfeiçoamento de Pessoal de Nível Superior (Brazil) for a grant to the first author.

\section{References}

AFTAB, F. and PREECE, J.H., 2007. Forcing and in vitro establishment of softwood shoots from large stem segments of woody plants. In: Z. Xu, J. Li, Y. Xue and W. Yang, eds. Biotechnology and Sustainable Agriculture 2006 and Beyond. Dordrecht: Springer, pp. 437-444.

AHMAD, I., HUSSAIN, T., ASHRAF, I., NAFEES, M., MARYAM, RAFAY, M. and IQBAL, M., 2013. Lethal effects of secondary metabolites on plant tissue culture. American-Eurasian Journal of Agricultural \& Environmental Sciences, vol. 13, pp. 539-547. http://dx.doi.org/10.5829/idosi.aejaes.2013.13.04.1975.

AHMAD, T., UR-RAHMAN, H., AHMED, C.H.M.S. and LAGHARI, M.H., 2003. Effect of culture media and growth regulators on micropropagation of peach rootstock GF 677 . Pakistan Journal of Botany, vol. 35, pp. 331-338.

ALI, A.A. and ALQURAINY, F., 2006. Activities of antioxidants in plants under environmental stress. In: N. Motohashi. The lutein-prevention and treatment for age-related diseases 2006. India: Transworld Research Network, pp. 187-256.

AZOFEIFA-DELGADO, Á., 2009. Problemas de oxidación y oscurecimiento de explantes cultivados in vitro. Agronomía Mesoamericana, vol. 20, no. 1, pp. 153-175. http://dx.doi. org/10.15517/am.v20i1.4990.

BRENZAN, M.A., SANTOS, A.O., NAKAMURA, C.V., DIAS FILHO, B.P., UEDA-NAKAMURA, T., YOUNG, M.C.M., CÔRREA, A.G., ALVIM JÚNIOR, J., MORGADO-DÍAZ, J.A. and CORTEZ, D.A.G., 2012. Effects of (-) mammea A/BB isolated from Calophyllum brasiliense leaves and derivatives on mitochondrial membrane of Leishmania amazonensis. Phytomedicine, vol. 19, no. 3-4, pp. 223-230. http://dx.doi. org/10.1016/j.phymed.2011.10.008. PMid:22285848.

CARVALHO, L.R., SILVA, E.A.A. and DAVIDE, A.C., 2006. Classificação das sementes florestais quanto ao comportamento no armazenamento. Revista Brasileira de Sementes, vol. 28, no. 2, pp. 15-25. http://dx.doi.org/10.1590/S0101-31222006000200003.

CHANG, S. and SHU, H., 2013. A method to suppress the browning in banana (Musa, AAA) embryogenic callus induced. Research Journal of Biotechnology, vol. 8, pp. 63-69.

COLE, R.J., HOLL, K.D., KEENE, C.L. and ZAHAWI, R.A., 2011. Direct seeding of late-successional trees to restore tropical montane forest. Forest Ecology and Management, vol. 261, no. 10, pp. 1590-1597. http://dx.doi.org/10.1016/j.foreco.2010.06.038.

DE KLERK, G.-J., 2002. Rooting of microcuttings: theory and practice. In Vitro Cellular \& Developmental Biology - Plant, vol. 38 , no. 5 , p. $415-422$.
FARZANA, A.F.R., BANDARA, R.M.I.E.K., ALUWIHARE, P.C. and EESWARA, J.P., 2010. In vitro regeneration of shoots from Garcinia quaesita leaf explants. Journal of the National Science Foundation, vol. 38, pp. 157-162.

FISCHER, E. and DOS SANTOS, F.A.M., 2001. Demography, phenology and sex of Calophyllum brasiliense (Clusiaceae) trees in the Atlantic forest. Journal of Tropical Ecology, vol. 17, no. 06, pp. 903-909. http://dx.doi.org/10.1017/S0266467401001675.

FLORES, E.M., 2002. Calophyllum brasiliense Cambess. In: J.A. Vozzo, ed. Tropical tree seed manual. Washington: USDA Forest Service, pp. 353-356.

FLORES, J.P., 2006. Inducing resistance of Spanish cedar Cedrela odorata L. and mahogany Swietenia macrophylla King against Hypsipyla grandella (Zeller) by grafting. Moscow: University of Idaho. Thesis.

GEORGE, E.F. and DAVIES, W., 2008. Effects of the physical environment. In: E.F. GEORGE, M.A. HALL and G. DE KLERK, eds. Plant propagation by tissue culture. 3rd ed. Dordrecht: Springer, vol. 1, pp. 423-464.

GEORGE, E.F. and DEBERGH, P.C., 2008. Micropropagation: uses and methods. In: E.F. GEORGE, M.A. HALL and G. DE KLERK, eds. Plant propagation by tissue culture. 3rd ed. Dordrecht: Springer, vol. 1, pp. 19-64.

GOH, H.K.-L., RAO, A.N. and LOH, C.-S., 1990. Direct shoot bud formation from leaf explants of seedlings and mature mangosteen (Garcinia mangostana L.) trees. Plant Science, vol. 68, no. 1, pp. 113-121. http://dx.doi.org/10.1016/0168-9452(90)90159-L.

GREGORY, J.F., 1996. Vitamins. In: O.R. FENNEMA, ed. Food chemistry. 3rd ed. New York: Marcel Dekker Inc, pp. 531-616.

ILIEV, I., GAHDOSOVÁ, A., LIBIAKOVÁ, G. and JAIN, S.M., 2010. Plant micropropagation. In: M.R. DAVEY and P. ANTHONY, eds. Plant cell culture: essential methods. Oxford: Wiley-Blackwell, pp. 1-23.

ITO, C., ITOIGAWA, M., MISHINA, Y., CECHINEL FILHO, V., MUKAINAKA, T., TOKUDA, H., NISHINO, H. and FURUKAWA, H., 2002. Chemical constituents of Calophyllum brasiliensis: structure elucidation of seven new xanthones and their cancer chemopreventive activity. Journal of Natural Products, vol. 65, no. 3, pp. 267-272. http://dx.doi.org/10.1021/np010398s. PMid:11908963.

JORDAN, M. and OYANEDEL, E., 1992. Regeneration of Pouteria lucuma (Sapotaceae) plants in vitro. Plant Cell, Tissue and Organ Culture, vol. 31, pp. 249-252.

KRIKORIAN, A.D., 1988. Plant tissue culture: perceptions and realities. Proceedings: Plant Sciences, vol. 98, no. 6, pp. 425-464.

LLOYD, G. and MCCOWN, B.H., 1980. Commercially feasible micropropagation of mountain laurel (Kalmia latifolia) by use of shoot tip culture. Combined Proceedings International Plant Propagators'Society, vol. 30, pp. 421-427.

MALIK, S.K., CHAUDHURY, R. and KALIA, R.K., 2005. Rapid in vitro multiplication and conservation of Garcinia indica: A tropical medicinal tree species. Scientia Horticulturae, vol. 106, no. 4, pp. 539-553. http://dx.doi.org/10.1016/j.scienta.2005.05.002.

MARQUES, M.C.M. and JOLY, C.A., 2000. Seed germination and growth of Calophyllum brasiliense (Clusiaceae), a typical species of flooded forests. Acta Botanica Brasilica, vol. 14, pp. 113-120. http://dx.doi.org/10.1590/S0102-33062000000100010. 
MAYNARD, B.K. and BASSUK, N.L., 1991. Stock plant etiolation and stem banding effect on the auxin dose-response of rooting in stem cuttings of Carpinus betulus L 'Fastigiata'. Plant Growth Regulation, vol. 10, no. 4, pp. 305-311. http://dx.doi. org/10.1007/BF00024590.

MEDEROS-MOLINA, S. and TRUJILLO, M.I., 1999. Elimination of browning exudate and in vitro development of shoots in Pistacia vera L. cv. Mateur and Pistacia atlantica desf. culture. Acta Societatis Botanicorum Poloniae, vol. 68, pp. 21-24.

MNG'OMBA, S.A., SILESHI, G., DU TOIT, E.S., and AKINNINFESI, F.K., 2012. Efficacy and utilization of fungicides and other antibiotics for aseptic plant cultures. In: D. DHANASEKARAN, N. THAJUDDIN and A. PANNERSELVAN. Fungicides for plant and animal diseases. Croatia: In Tech, pp. 245-254.

NAIR, L.G. and SEENI, S., 2003. In vitro multiplication of Calophyllum apetalum (Clusiaceae), an endemic medicinal tree of the Western Ghats. Plant Cell, Tissue and Organ Culture, vol. 78, no. 2, pp. 169-174. http://dx.doi.org/10.1023/A:1025001214995.

NAS, M.N. and READ, P.E., 2004. Improved rooting and acclimatization of micropropagated hazelnut shoots. Hort. Sci., vol. 39, pp. 1688-1690.

NĀWAR, W.W., 1996. Lipids. In: O.R. FENNEMA, ed. Food chemistry. 3rd ed. New York: Marcel Dekker Inc, pp. 225-320.

NEONDO, J., MACHUA, J., MUIGAI, A., NYENDE, A.B., MUNJUGA, M., JAMNADASS, R. and MUCHUGI, A., 2011. Micropropagation of Allanblackia stuhmannii: amenability to tissue culture technique. International Journal of Biotechnology and Molecular Biology Research, vol. 2, pp. 185-194.

NERY, F.C., ALVARENGA, A.A., JUSTO, C.F., DOUSSEAU, S. and VIEIRA, C.V., 2007. Efeito da temperatura e do tegumento na germinação de sementes de Calophyllum brasiliense. Ciência e Agrotecnologia, vol. 31, no. 6, pp. 1872-1877. http://dx.doi. org/10.1590/S1413-70542007000600041.

NIEDZ, R.P. and BAUSHER, M.G., 2002. Control of In vitro contamination of explants from greenhouse- and field-grown trees. In Vitro Cellular \& Developmental Biology - Plant, vol. 38 , no. 5 , pp. $468-471$.

NOLDIN, V.F., ISAIAS, D.B. and CECHINEL FILHO, V., 2006. Gênero Calophyllum: importância química e farmacológica. Quimica
Nova, vol. 29, no. 3, pp. 549-554. http://dx.doi.org/10.1590/ S0100-40422006000300025.

RAJU, P.S. and BAWA, A.S., 2006. Food additives in fruit processing. In: Y.H. HUI, ed. Handbook of fruits and fruits processing. Iowa: Blackwell Publishing, pp. 145-170.

RATHORE, M.S., RATHORE, M.S. and SHEKHAWAT, N.S., 2013. Ex vivo implications of phytormones on various in vitro responses in Leptadenia reticulata (Retz.) Wight.\&Arn. - an endangered plant. Environmental and Experimental Botany, vol. 86, pp. 86-93. http://dx.doi.org/10.1016/j.envexpbot.2010.05.009.

SÃO PAULO. Secretaria do Meio Ambiente do Estado de São Paulo, 2008. Resolução SMA-8, de 31 de janeiro de 2008 (ANEXO). Listagem das espécies arbóreas e indicação de suaocorrência natural nos biomas, ecossistemas e regiões ecológicas no Estado de São Paulo. Diário Oficial do Estado de São Paulo, São Paulo.

SOUZA, M.C., BESERRA, A.M.S., MARTINS, D.C., REAL, V.V., SANTOS, R.A.N., RAO, V.S., SILVA, R.M. and MARTINS, D.T.O., 2009. In vitro and in vivo anti-Heliobacter pylori activity of Calophyllum brasiliense Camb. Journal of Ethnopharmacology, vol. 123, no. 3, pp. 452-458. http://dx.doi.org/10.1016/j. jep.2009.03.030. PMid:19501278.

SUÁREZ, E., PÉREZ-FRANCÉS, J.F. and RODRÍGUEZ-PÉREZ, J.A., 2010. Use of multinodal explants for micropropagation of Leucodendron 'Safari Sunset'. Spanish Journal of Agricultural Research, vol. 8, no. 3, pp. 790-796. http://dx.doi.org/10.5424/ sjar/2010083-1280.

SUBBAIAH, M.M. and MINOCHA, S.C., 1990. Shoot regeneration from stem and leaf callus of Eucalyptus tereticornis. Plant Cell Reports, vol. 9, no. 7, pp. 370-373. http://dx.doi.org/10.1007/ BF00232401. PMid:24227057.

THENGANE, S.R., BHOSLE, S.V., DEODHAR, S.R., PAWAR, K.D. and KULKARNI, D.K., 2006. Micropropagation of Indian laurel (Calophyllum inophyllum), a source of anti-HIV compounds. Current Science, vol. 90, pp. 1393-1397.

ZHOU, B., WEI, X., WANG, R. and JIA, J., 2010. Quantification of the enzymatic browning and secondary metabolites in the callus culture system of Nigella glandulifera Freyn et Sint. Asian Journal of Traditional Medicines, vol. 5, pp. 109-116. 